\title{
Arrangement for rational use and conservation of land resources in Rostov region
}

\author{
Natalia Ovchinnikova ${ }^{1, *}$, Daria Burdova $^{1}$, and Maria Garanova ${ }^{1}$ \\ ${ }^{1}$ Don State Technical University, 344022, 162 Socialisticheskaya, Rostov-on-Don, Russia
}

\begin{abstract}
This article covers the problem of rational use of land taking into account the economic and environmental aspects, aiming to eliminate any irrational use of land plots in the future. For this reason, it specifies the parameters characterizing the components of a rational land use concept, namely, its compliance with the intended use, sustainable soil fertility and environmental situation. The achievement of rationalization often contradicts the basic objectives of the concept of territorial development. To avoid such contradictions, the authors disclose the principles of rational land use. As of today, the concept of rational land use covers aspects in various spheres, such as ecology, economics, sociology, and, besides, affects environmental measures. Land resources management refers not only to the use of land resources, when natural and economic conditions and properties of the territory are the most fully taken into account, the fundamental socio-economic interests of the society are ensured, high efficiency of production and other activities is achieved, and the productive and other soil properties are recovered and ensured, but also to the possibility of using land by legitimate land users.
\end{abstract}

\section{Introduction}

Complex work plays one of the most important roles in the concept of rationality.

It is the quality of the complex work, that influences the reliability of land plots data.

The Russian Federation has an extensive land fund, which is a great asset to our country. Therefore, every land plot is to be used in strict compliance with the current legislation[1].

Currently, the problem of low quality of complex work necessary for qualitative and quantitative registration of land plots leads to the irrational use of the territory of the entire country.

In accordance with the existing legislation of the Russian Federation, land is the basis for life and activity of people inhabiting a respective territory. Land fund is essential to the limits of a state sovereignty meaning that the aggregate land in a given territory with a particular legal regime provides independence to this state. It should be understood that no state can exist without its territory being strictly defined and established.

A concept of rational land use is the most sophisticated and multifaceted.

\footnotetext{
* Corresponding author: donong160875@yandex.ru
} 
Firstly, rationality means relevance of land use, i.e. conformity of land allocation to the purposes and tasks of a specific production. Therefore, rationality cannot be referred only to agriculture or any other industry [2].

Secondly, the State standard defines this concept as "maximizing effect by all land users in the production process in achieving purposes of land management taking into account land conservation and optimal interaction with natural factors".

Thus, we can say that rational use of land consists of two aspects: economic and environmental which are closely interrelated. The essence of the economic aspect of rational use is considered to be the maximum usefulness of natural resources management, and of environmental aspect - the complex nature of natural resources management.

Thirdly, some clarification in the definition of rationality has been introduced by Civil law, namely, by Art. $285 \mathrm{CC}$, where the following three grounds for deprivation of rights to land plot as a result of irrational land use are stipulated, namely:

- Improper use;

- Use that has led to a significant decrease in the fertility of the agricultural land;

- Use resulting in significant environmental degradation.

The above specifies three parameters being a concept of rational land use, namely: compliance with the purpose of land use, maintaining land fertility and environmental conditions[3].

\section{Materials and methods}

Almost every phenomenon or object of the physical world has two main aspects: quantitative and qualitative. And criteria for rational use of land shall be determined from this perspective.

A quantitative criterion for rational use of land is expressed in two basic parameters:

a) economical use of land due to the need to resolve a contradiction between limited land mass of a state and increasing demand for land required to accommodate production facilities etc., expanding plowing areas to meet the demand for food for a growing population. Therefore, when allocating land under buildings and construction, such allotted area must be reasonably justified or not exceed the allotment limits established by respective regulatory enactments;

b) economical use of land shall be achieved not only through saving land when making allotments for certain objects, but also through rational combination of the facilities being placed. For example, through combining power lines with roads; application of easements for adjacent plots (approach, passage) with the aim not to allocate any additional land under railroad tracks, etc[4].

A qualitative criterion for rational use of land means, first of all, maintaining a production force as the key instrument for agricultural production that is to:

- Establish an obligation for all land users which perform any soil disturbing work, to strip of, store and not disturb the fertile topsoil that is able to enhance the fertility power of soil even if being separated from its parent rock (as a means to recultivation of other agricultural land when being used in greenhouses, plant nurseries);

- Restrict the use of agricultural land for non-agricultural needs. In particular, agricultural land is subdivided into ordinary, valuable, and most valuable, and, depending on its value, in exceptional cases, such land can be allocated for non-agricultural needs or in general prohibited to be allocated for such purposes;

- Establish a universal obligation for all land users (owners, land proprietors, and tenant farmers) to enhance the soil fertility regardless of its natural qualities;

- Allocate for agricultural needs such land that is not suitable for farming or some land of poorer quality; 
- Establish a universal obligation to protect soil from erosion, infection, contamination, and any other negative consequences since soil erosion, for example, consumes daily more than 40 ha on the globe including in result of natural processes (sweeping away by rainwater, drifting etc.).

When the quantitative criterion of rational land use prevails in a non-agricultural sphere of land use, the qualitative criterion prevails in an agricultural one. At the same time, both quantitative and qualitative criteria "work" for the agricultural land use. If a shortage of land area can be compensated in non-agricultural sector by engineering solutions (in housing sector - by the construction of multistory buildings; in transport and industrial sectors - by the construction of underground structures, etc.), then any shortage of land suitable for agricultural use is generally irretrievable. Given that agriculture is vital for the human beings, loss of this property would be catastrophic[5].

\section{Discussion}

Therefore, rational land use has two main aspects: from a quantitative point of view, it involves land conservation, prevention of wasteful allotment of land plots under nonagricultural objects, and, from a qualitative point of view, entails ensuring soil fertility, non-deterioration of soil quality etc. [6].

\subsection{Indicators of rational land use in the Rostov Region}

As of January 1, 2019, the land fund of the Rostov Region has comprised 10,096.7 thousand ha and its breakdown by land categories is shown on figure 1:

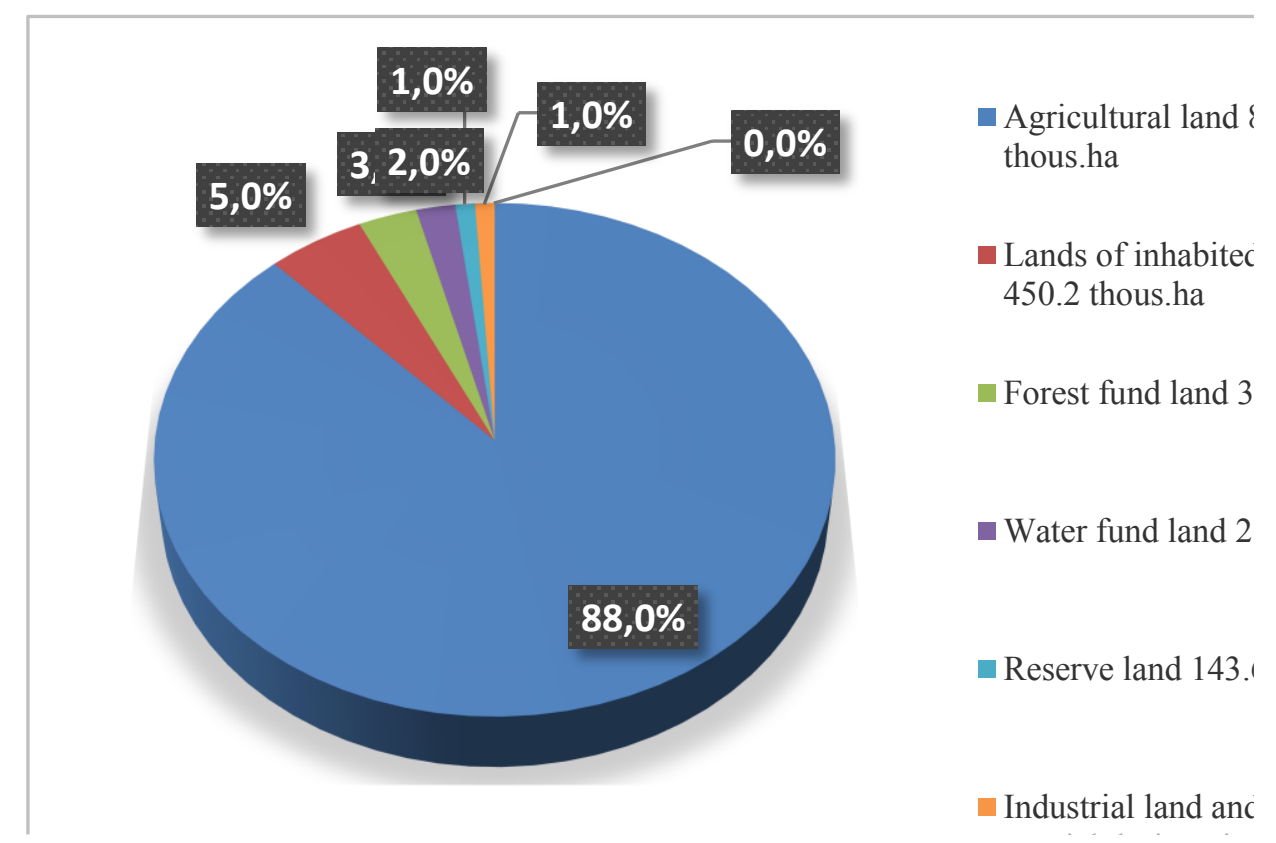

Fig. 1. Land fund of the Rostov Region by categories.

According to the results of land demarcation, the Russian Federation has been declared to have an ownership of land having the area of 659.9 thousand ha, and the Rostov region 25.8 thousand ha. The breakdown of these figures by land categories is given in Table 1.1 
Table 1. Information on land availability and distribution by category and form of ownership.

\begin{tabular}{|c|c|c|c|c|c|c|c|c|}
\hline \multirow[b]{2}{*}{$\begin{array}{l}\text { Item } \\
\text { Nos. }\end{array}$} & \multirow[b]{2}{*}{ 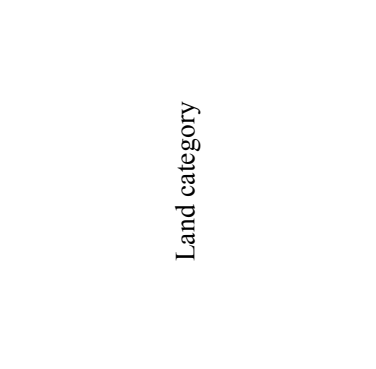 } & \multirow[b]{2}{*}{ 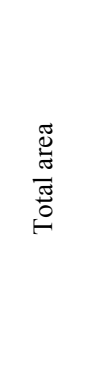 } & \multirow[b]{2}{*}{ 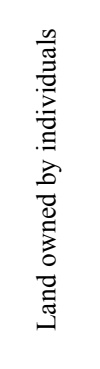 } & \multirow[b]{2}{*}{ 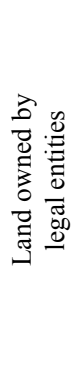 } & \multirow[b]{2}{*}{ 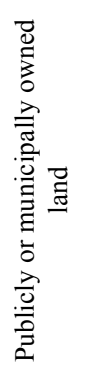 } & \multicolumn{3}{|c|}{ Of which } \\
\hline & & & & & & 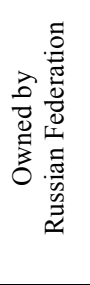 & 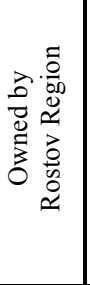 & 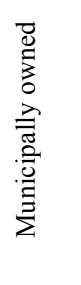 \\
\hline 1 & 2 & 3 & 4 & 5 & 6 & 7 & 8 & 9 \\
\hline 1 & Agricultural land & $8,833.9$ & $6,075.3$ & 675.1 & $2,083.5$ & 216.4 & 11.7 & 122 \\
\hline 2 & Land of residential settlements & 450.2 & 143.5 & 15.4 & 291.3 & 17.2 & 2.6 & 15.9 \\
\hline 3 & $\begin{array}{l}\text { Land designated for industrial, } \\
\text { power generation, transport, } \\
\text { telecommunications, radio- } \\
\text { broadcasting, IT, space industry, } \\
\text { national defense, and security use } \\
\text { and land with other special } \\
\text { designated uses. } \\
\text { Of which: }\end{array}$ & 95.7 & 0.6 & 3.1 & 92.0 & 45.0 & 11.4 & 1.3 \\
\hline & Railway transport & 20.2 & - & - & 20.2 & 18.8 & - & - \\
\hline & Road transport & 27.0 & - & 0.1 & 26.9 & 3.4 & 9.7 & 0.1 \\
\hline & Defense and security & 28.5 & - & - & 28.5 & 21.6 & - & - \\
\hline 4 & $\begin{array}{l}\text { Land of specifically protected } \\
\text { territories and objects }\end{array}$ & 11.4 & 0.3 & - & 11.1 & 9.6 & 0.1 & 0.1 \\
\hline 5 & Land of forest fund & 344.8 & - & - & 344.8 & 338.0 & - & - \\
\hline 6 & Land of water fund & 217.1 & - & - & 217.1 & 33.6 & - & - \\
\hline 7 & Reserved land & 143.6 & - & - & 143.6 & 0.1 & - & - \\
\hline & Total land: & $10,096.7$ & $6,219.7$ & 693.6 & $3,183.4$ & 659.9 & 25.8 & 139.3 \\
\hline
\end{tabular}

It can be thus seen that the land fund of the Rostov Region is as extensive and diversified as the land fund of the Russian Federation. On this territory there are all land categories, a large number of various areas, and major types of land ownership[7].

The focus areas of rational land use can be defined by the following long-term goals:

- Stabilization of natural environment by creating a system of stabilizing and specially protected areas capable of maintaining the environmental balance;

- Preventing land degradation;

- Rehabilitation of land properties and qualities lost in result of degradation and irrational business activity that correspond to certain environmental conditions;

- Transition to resource-saving technologies and systems for rational land management[8].

Processes of achieving rationalization by certain methods often conflict with basic objectives of this concept. In order to avoid such discrepancies, the following principles of rational use of land shall be observed: 
- Mitigating negative impacts of agricultural production;

- Stimulating natural functioning of biosphere;

- Monitoring condition of soil cover. Along with monitoring fertile topsoil current indicators, rational use of land involves more extensive examination of resources aiming to identify general trends in the changes in the geotechnical structure of the natural tract.

- Improving and upgrading agricultural production technologies in order to minimize inputs and reduce any harmful impact on soil.

- Restoring original properties of land fund. Both as a result of impact of environmental factors and technological disasters, resources natural properties can be affected. Ultimately, such changes entail the need to use methods of recultivation, anti-erosion protection, restoration of forest areas, construction of hydrological facilities, etc [9].

State regulation of land policy also plays a significant role in legal support of the rules for rational use of agricultural territories. Of key importance from this position are the rules of land protection. This is a whole complex of not only legal, but also technical tools aimed at reducing any harmful impact on fertile layer by industrial enterprises, transport, mining enterprises, engineering structures, etc.

How in practice are the rational use and protection of land arranged? It all starts with the aforementioned planning that provides for the safe location of agricultural facilities in terms of proximity to pollution sources, in particular. In the future, those legal norms will be in force, which exclude constructing the same industrial and engineering enterprises in a certain radius with respect to the used land funds. Another area of land protection involves the implementation of a wide range of appropriate reclamation and rehabilitation measures.

Laws and regulations for rational use of land in the Russian Federation:

- Federal law No.78-FZ (rev. 31.12.2017) “On Land Management” dated 18.06.2001;

- "Land Code of the Russian Federation" No.136-FZ (rev. 02.08.2019) dated 25.10.2001;

- $\quad$ Federal law No.264-FZ (red. 25.12.2018) "On Development of Agriculture" dated 29.12.2006.

The focus areas of rational use of land resources can be defined by the following long-term objectives:

- Stabilization of natural environment through creating the system of stabilizing and specially protected nature areas capable of maintaining an ecological balance;

- Preventing land degradation;

- $\quad$ Restoration of properties and qualities of the land lost in result of degradation and irrational economic activity that meet certain environmental conditions;

- Transition to resource-efficient technologies and systems of economic land use.

Principles of rational land use

Processes of achieving rationalization by certain methods can frequently conflict with the basic goals of this concept. In order to avoid such discrepancies, it is necessary to abide by the following principles of rational land use:

- Mitigating negative impacts of agricultural production.

- Stimulating natural functioning of biosphere.

- Monitoring condition of topsoil. Together with monitoring of fertile topsoil current indicators, any rational use of land involves examination of resources at deeper levels entailing identification of general trends in changing geotechnical structure of the natural tract.

- Improving and upgrading farming technologies aiming to minimize inputs and mitigate harmful impact on topsoil.

- Restoring original properties of land fund. Some natural characteristics of the resource can be affected both as a result of impact of natural processes and anthropogenic conditions. Ultimately, such changes entail the need to apply some methods of restoration, 
anti-erosion protection, regeneration of forest areas, construction of hydrological objects etc [10].

State regulation of the land policy also plays an important role in legal support to the rules of rational use of agricultural areas. In this context, the rules of land conservation are of key importance. These are a complex of not only legal but also technical instruments aimed to mitigate any harmful impacts of industrial enterprises, transport, mining enterprises, engineering structures etc. on the fertile topsoil. How is rational land use and land conservation arranged in practice? It all starts with the a.m. planning which provides for a safe positioning of agricultural objects in terms of their proximity in particular to any contamination sources. Further, special legal norms are in force, which make it impossible to construct these industrial and engineering enterprises within a specific radius to land funds being used. Another area of land protection involves implementation of a wide range of recultivating and restoring activities [11].

According to the Urban Development Code of the Russian Federation, land of urban and rural settlements is used on the basis of urban-development documentation on townplanning development of urban and rural settlements, other municipal authorities, and urban-planning documents on the development of territories of urban and rural settlements.

Therefore, rational use of municipal land is generally based on town-planning documentation as these are the documents which provide grounds for planning the development of a municipality territory as well as organization of use of urban and rural settlements territories.

The town planning documentation on urban planning for the development of territories of urban and rural settlements and other municipalities includes as follows:

- Territorial integrated town-planning schemes for the development of districts (counties) and rural areas (regions, rural councils);

- Master plans of urban and rural settlements;

- Projects within the limits of urban and rural settlements, other municipal entities.

Urban-planning documentation on the development of territories of urban and rural settlements includes the following:

- Draft site plans for urban and rural settlements (hereinafter as the "Draft site plan");

- Area demarcation plans;

- Housing development schemes of blocks, sub-districts, and other elements of the development pattern of urban and rural settlements (hereinafter as the "Housing development scheme").

Rational use of land should be predetermined at a stage of territory zoning, inclusion of a land plot into a certain category, and land allocation to one or another enterprise. Therefore, the completeness and efficiency of land use shall be determined in compliance with its designated use [12].

Completeness of land use means the ratio of the area being actually used according to its designated purpose to the total area of allotted territory, land-use or land plot. For example, the completeness of land use of an agricultural enterprise can by characterized by the ratio of area of agricultural land and total area of land-use, the completeness of land use of a settlement - by the ratio of built-up and unbuilt areas; the completeness of use of state reserve land - by the ratio of territory provided for use or lease to actually non-demanded territory.

There are no available universal methods and technologies that ensure rational land use. In each case, on a planning stage, some specific approaches are to be chosen which will enable to achieve the goals. What does the planning mean in this particular case? This is organization of land management and control within a specific municipal and agricultural object based on a specific set of applicable technical means and rules. When planning rational land use, the following activities are to be carried out: 
1.Zoning of land areas according to their natural and agricultural features.

2. Considering prepared proposals on rational land use.

3. Land management. Boundary settlement of land plots (demarcation).

4. Identification of land funds to be included into special registers.

5. Besides, no planning is possible without a preliminary survey of the area where land funds are planned to be established. From this point of view, for rational organization of land use the following data will be of significant importance:

6. Mass valuation of land based on its agricultural characteristics.

7. Geodetic, cartographic, and hydrological data on the terrain.

8. The latest data on land monitoring (if available).

The a.m. data will enable planners to initially appropriately allocate any land plots depending on their operational capacity. In the future, taking into account the external conditions of land use, a strategy for the rational use of land will be developed with the initial data being economic and technological capabilities of its owner [13].

Measures and principles of rational land fund management are nearly always implemented in several ways. Only with a comprehensive change in approaches to the use of natural resources it is possible to achieve high positive results. Main ways of rational land use include the following:

1.Human factor. Perhaps, the most influential factor through which both favorable and negative impact on land use processes is exerted. Positive regulatory measures with a focus on optimizing tillage system include the introduction of haymaking-pasture rotation, renewal of saiylyks (summer houses), land clearing operations on degraded land areas, reducing contamination of fertile topsoil with agricultural wastes.

2.Production process. Technologies for soil mechanical processing are actively developing in ergonomic, functional and power specifications. However, improved technical efficiency of soil tillage tools does not always comply with the standards of balanced maintaining the soil fertility. Therefore, conventional processing methods are being replaced by optimized concepts for land preparing for planting. Zero tillage technology, for example, presupposes combining several operations in one technological process.

3. Agricultural climatic conditions. Indicators of moisture content and thermal effect on land also determine its fertility and suitability for tillage. Therefore, in terms of agroclimatic impact, some measures for rational use of land have been developed with the purpose to ensure optimal temperature and humidity balance. From this point of view, land improvement can be referred to the most common complex of operations.

Having considered land use in the Russian Federation and rational use of municipality land, the following conclusions may be drawn:

- Municipality land is a more specific area of land use rationalization;

- Different regulatory and legal framework;

- Different measures applied;

- $\quad$ Different levels of responsibility [14].

\section{Conclusions}

It shall be noted that each citizen bears personal responsibility for rational use of land resources of the Russian Federation.

Pursuant to the Land Code and the Administrative Offense Code, any misuse of land resources is punishable under administrative and criminal law.

In order to maintain the optimal state of the territory, it is necessary to understand how it can be used rationally. 
The main directions of rational use of land resources can be determined by the following long-term goals:

- Stabilization of the natural environment by creating a system of stabilizing and specially protected areas capable of maintaining an environmental balance;

- $\quad$ Preventing land degradation;

- Rehabilitation of land properties and qualities lost in result of degradation and irrational business activity that correspond to certain environmental conditions;

- Transition to resource-saving technologies and systems for rational land management [15].

\section{References}

1. Immovable Property Cadastre, Cadastral activity in Russia: Experience of the present and prospects of the future, The 6th All-Russian Congress of Cadastral Engineers (Moscow, 2017)

2. M. Ogryzek, R.Wisniewski, Tom Kauko, Real Estate Management and Valuation, 26(3) (2018). https://doi.org/10.2478/remav-2018-0022

3. N. Ovchinnikova, D. Burdova, M. Garanova, E3S Web of Conferences, 91 (2019). https://doi.org/10.1051/e3sconf/20199108023

4. T. S. Wilson, B.M. Sleeter, R. R. Sleeter, Ch. E. Soulard, Land, 3(2) (2014). https://doi.org/10.3390/land3020362

5. J. Wójcik-Leńa, K. Sobolewska Mikulska, N. Sajnóg, P. Leń, Land Use Policy, 78 (2018). https://doi.org/10.1016/j.landusepol.2018.06.044

6. W. Han, X. Zhang, X. Zheng, Land Use Policy, 92 (2020) https://doi.org/10.1016/j.landusepol.2019.104432

7. N.G. Ovchinnikova, MATEC Web of Conferences, 10.1051/matecconf $/ 201710601004$

8. N.G. Ovchinnikova, Terra economicus 7(2), 41-44 (2009)

9. V.A. Chudovska, Balanced Nature Using, Institute of agroecology and environmental management, 7(4) (2016)

10. S. Lai, F. Leone, C. Zoppi, Sustainability, 9(12) (2017). https://doi.org/10.3390/su9122174

11. S.G.Sheina,.A.Khamavova, Procedia Engineering, $150 \quad$ (2016). https://doi.org/10.1016/j.proeng.2016.07.198

12. Ole Mertz, C. Filt Mertens, World Development, 98 (2017). https://doi.org/10.1016/j.worlddev.2017.05.002

13. M. Lengoiboni, C. Richter, Jaap Zevenbergen, Land Use Policy, 85 (2019). https://doi.org/10.1016/j.landusepol.2019.03.023

14. Ben Gilbey, J. Davies, G. Metternicht, C. Magero, Environmental Science \& Policy, 100 (2019). https://doi.org/10.1016/j.envsci.2019.04.007

15. D. Smiraglia, T. Ceccarelli, S. Bajocco, L. Salvati, L. Perini , Environmental Research, 147 (2016). https://doi.org/10.1016/j.envres.2015.11.030 